\title{
Sustainable development of grassland forage production in conditions of climate change
}

\author{
Petrychenko V. ${ }^{1}$, Korniichuk O. ${ }^{2}$, Veklenko Yu. ${ }^{3}$ \\ Institute of fodder crops and agriculture of Podillia of NAAS, Yunosti avenue, 16, Vinnytsia, 21100, Ukraine; e- \\ mail: 3yuri.veklenko@gmail.com
}

The purpose. To develop effective models and systems of grassland forage production on natural forage lands of various soil and climatic regions of the country on the basis of adaptive technologies for the creation and use of hay-pasture grass stands. Methods. Analysis, synthesis, generalization, field experience. Results. Theoretical justification is made and ways are outlined for further perfecting grassland systems and techniques of building cultivated grasslands for rural communities with the purpose of intensification of milk cattle husbandry of Ukraine, solution of ecological problems and heightening economic efficiency of perspective for production of innovative development. Directions of production of high-quality feedstuff and approaches to preserving biodiversity in grassland systems in conditions of global climate fluctuations are shown. Conclusions. Modern development of grassland forage production should be based on ecological-biological principles of formation of the dominant adapted pascual agrophytocenosis and new systems of grazing depending on climatic and anthropogenous factors. Implementation of innovative developments will raise productivity of animal husbandry in public sector, will create premises to augmentation of cattle stock and stability improvement of traditional milk cattle husbandry to climate fluctuations.

Key words: public pastures, natural forage grasslands, pasturable grass stands, meadow forage production, quality of feedstuff.

https://doi.org/10.31073/agrovisnyk201806-04

Introduction. Forage resources of natural grasslands are an important reserve of milk production. In Ukraine haylands and pastures occupy about 7.9 million hectares or $19 \%$ of agricultural lands. Flood plains and lowland meadows suitable for haymaking predominate in the Forest-Steppe and Polissya, while dry lands and step agrophytocenoses that are low productive and used mainly as pastures prevail in the Steppe zone [5]. Two thirds of these lands are owned by non-organized sector of agribusiness, their major form of use is the unsystematic uncontrolled cattle grazing and extensive (in later phases of development) system of grass mowing, which does not let them completely fulfil their biological potential. Thus, pastures provide $9.8 \mathrm{t} / \mathrm{ha}$ of green mass and 2.4 tons per hectare of hay from hayfields in Polissya, $14.3 \mathrm{t} / \mathrm{ha}$ and $2.6 \mathrm{t} / \mathrm{ha}$, respectively, in the Forest-Steppe, and 6,3 t/ha of green mass in the Steppe [1]. In the complex of measures aimed at increasing the productivity of dairy cattle and reducing the production cost, low-cost technologies for grazing dairy livestock on the cultivated pastures have considerable potential. Therefore, it is an urgent task for Ukraine to solve the problem of resource conservation and to improve the quality of green fodder, primarily through the development of fundamentally new approaches and technologies for the creation of common pastures in the reformed rural communities.

Statement of the problem. Nowadays grassland forage production is extensive and underdeveloped. Significant achievements of science are being slowly introduced into agrarian production. The bulk of the potential areas under cultivated pastures are located on the natural forage grasslands. It is here that summer grazing of household cattle is practiced. Lack of cultivated pastures leads to inefficient use of lands, reduction of areas intended for harvesting of forages. Unfortunately, a public opinion about the ecological and economic significance of cultivated pastures has failed to be formed. In the last decades, activities on the improvement of pastures have almost been stopped, although inexhaustible fodder reserves are available since even low-cost practices increase grass yield and forage quality 1.5-2 times [11]. No matter what global climate changes are, there are reserves for improvement of the productivity of forage grasslands. Recently agricultural corporations have introduced technologies of the single-type feeding of dairy cattle. At the same time, the issue of supply of high-yielding cows with pasture forage is omitted.

Many leaders of agricultural enterprises, mainly those who have never dealt with the organization of the single-type feeding of cows, share contradictory opinions about the most cost-effective summer feeding of animals. As a rule, these are cost-beneficial farms supplied with the appropriate equipment, seeds, fertilizers, and specialists. It has become organizationally easier to use milking rooms than in the case of pasture keeping. 
But the transition to this technology can turn into significant economic losses and the emergence of environmental problems as well. Problems related to the health of cows, their reproductive functions can be directly compared with the preserved feeds of poor quality and high level of concentrates in the diets under single-type feeding [9]. It may result in the lowest level of efficient use of fertile soils and extensive grassland management.

Therefore, at the stage of integration to the $\mathrm{EU}$, where the requirements for feeds and milk quality are very high, the main objective of grass farming is to develop effective models and systems of production of high quality forage from natural forage grasslands in different soil and climatic regions of the country through the use of new varieties of grasses and forage crops, and adaptive technologies of their cultivation. Productive potential of the natural forage grasslands is rather significant under effective improvement, i.e. they can provide additionally $54.8 \mathrm{mln} \mathrm{t}$ of green mass and $5.7 \mathrm{mln}$ t of hay in Ukraine [2].

Results and discussion. Pasture keeping is prevalent for the cattle all over the world. In Europe, pasture green forage is the basis of the annual feeding of the vast majority of ruminants. Hay-pasture grasslands make up more than $40 \%$ in the general balance of agricultural lands of the EU countries. Due to decrease in the acreage of agricultural lands caused by urbanization, their environmental role remains substantial and relatively stable [10].

In Great Britain, where economic efficiency of this industry is very high, grass farming is the main source of income for nearly $65-70 \%$ of the domestic farmers. In Ireland, where the supply of pasture forage in the first cycle of pasturing is twice higher than the needs of animals grazed, $50 \%$ of the total number of pastures in the first cycle is used for grazing, others are mowed. In the Netherlands, $75 \%$ of the total pasture area are usually pastured, and the rest $25 \%$ are intended for mowing. In Ireland the surplus of pasture forage at the beginning of the season allows to allocate permanent pastures for mowing each year, while in the Netherlands, due a smaller stock of pasture forage before the first cycle, it is more efficient to implement the system where all pasture units are grazed and mowed in rotation during the season. Single mowing is carried out at all pastures, half of them are mowed twice. The experience of Great Britain shows that the creation of cultivated high-yielding pastures, even by $50 \%$ of their total area, enables to meet the daily need of ruminants in the metabolizable energy and protein for more than $80 \%$ [7]. In the Western Europe, productivity of hay pastures comprises 12 t/ha of dry matter in the Netherlands, 4.5-5.0 t/ha in France, 6.0 t/ha in the Federal Republic of Germany, 8.0 t/ha in Belgium, $9.0 \mathrm{t} / \mathrm{ha}$ in Denmark. In the Northern countries, their average productivity is about $4.0 \mathrm{t} / \mathrm{ha}$ of dry matter [10].

On the cultivated pastures, in the early summer, a high-yielding cow provides itself with the energy sufficient for high milk yields (up to $25-30 \mathrm{~kg}$ per day). In this case, productive effect of forage by the protein is over $30 \mathrm{~kg}$ per day. Consumption of $12 \mathrm{~kg}$ of dry matter of pasture forage by cows guarantees $12 \mathrm{~kg}$ of milk without concentrates, $14 \mathrm{~kg}$ of dry matter gives the opportunity to get $16 \mathrm{~kg}$ of milk, and $16 \mathrm{~kg}$ of dry matter provides 20 $\mathrm{kg}$ of milk without concentrates [8]. Pasturing of livestock contributes to the proper development of animals, strengthens immunity, and creates favourable conditions for healthy offspring as well as the growth and development of young animals. If the nutritive value of green mass is taken to be $100 \%$, then it will equal $50 \%$ in hay, and $60-70 \%$ - in silage. When the exchange energy concentration per $1 \mathrm{~kg}$ of dry matter is $11 \mathrm{MJ}$, then the grass of cultivated pastures is equivalent to corn silage harvested in the phase of milk-wax ripeness of grain. By the content of protein and vitamins, the grass of cultivated pastures meets the needs of high-yielding cows and ensures higher milk yields than when fed with preserved feeds.

On the other hand, pastures are a key factor of the economic efficiency of milk production (Table 1). Grasses on the pastures are 2-3 times cheaper than any other forage. And this saving of the forage cost is not a shortterm benefit, since cattle can be pastured for 150-160 days each year. Our research has found that summer stable keeping, compared to pasturing, requires 1.6-2.3 times more aggregate energy expenditures, and 6.6-6.9 times more fuel and lubricants [6].

Table 1 - Comparative assessment of the effectiveness of pasture keeping of dairy cows

\begin{tabular}{|l|c|c|c|}
\hline \multirow{2}{*}{ Indicators } & \multicolumn{2}{c|}{ The level of pasture forage production } \\
\cline { 2 - 4 } & Low & Average & High \\
\hline Annual dry matter output per pasture, kg/ha & 2000 & 6000 & 10000 \\
\hline Milk productivity of cows, kg/year & 6000 & 6000 & 6000 \\
\hline Grazing pressure, cows/ha & 2,5 & 2,5 & 2,5 \\
\hline Annual milk production, kg & 15000 & 15000 & 15000 \\
\hline Milk productivity at the expense of pasture forages, $\mathrm{kg} / \mathrm{head} / \mathrm{year}$ & 1000 & 3000 & 5000 \\
\hline Annual milk production at the expense of pasture forages, kg/ha & 2500 & 7500 & 12500 \\
\hline
\end{tabular}




\begin{tabular}{|l|c|c|c|}
\hline Consumption of concentrates, $\mathrm{kg} / \mathrm{head} / \mathrm{year}$ & 2500 & 1500 & 500 \\
\hline Annual consumption of concentrates, kg/ha & 6250 & 3750 & 1250 \\
\hline Annual consumption of protein from concentrates, kg/ha & 250 & 100 & 25 \\
\hline Annual consumption of protein from pasture forages, kg/ha & 200 & 300 & 425 \\
\hline
\end{tabular}

The cost of forage from pasture grasses as a source of high-nutritional feeds is lower than the cost of concentrates in the EU countries, i.e. in Belgium - 4.4 times, the UK - 4.8, the Netherlands - 3.6, Germany -6 times. Creation of pastures from legume-cereal grasses with the inclusion of white clover (Trifolium repens L.) ensures saving of up to $300 \mathrm{~kg} / \mathrm{hectare}$ of mineral nitrogen and reduces production cost of green fodder at least 2.5 times compared with cereal grasses fertilized with high rates of mineral nitrogen [9].

Among the developments in grassland farming, which are of great interest for the specialists and practices abroad, there is a new system of rotated pasture use, which involves the rotation of grazing with the obligatory regime of additional feeding with bulky feeds, i.e. prewilted silage, hay, pulp etc. This system of pasture keeping of dairy cows has become most widely spread in the UK, Scandinavian countries and it is called "buffer grazing". Even taking into account the costs of silage production (10-15\%), the ratio of grass use under buffer grazing is $15 \%$ higher than in the case of conventional one (Table 2 ).

Table 2 - Estimation of efficiency of the system of pasture use by the productive forage effect

\begin{tabular}{|c|c|c|c|c|c|c|}
\hline Grazing system & $\begin{array}{c}\text { The number of } \\
\text { pasturing per } \\
\text { season }\end{array}$ & $\begin{array}{c}\text { Phase of grass } \\
\text { development during } \\
\text { grazing }\end{array}$ & $\begin{array}{c}\text { Pasture forage } \\
\text { output, } t / \text { ha }\end{array}$ & $\begin{array}{c}\text { Dry matter } \\
\text { output, } t / \text { ha }\end{array}$ & $\begin{array}{c}\text { Feed unit } \\
\text { output, } t / \text { ha }\end{array}$ & $\begin{array}{c}\text { Milk output } \\
\text { per season } \\
\text { from a } \\
\text { pasture, } \\
\text { t/ha }\end{array}$ \\
\hline $\begin{array}{c}\text { Non- } \\
\text { systematic }\end{array}$ & 3 & $\begin{array}{c}\text { Leaf-tube formation } \\
\text { ear formation }\end{array}$ & 30,0 & 7,2 & 5,0 & 4,8 \\
\hline Pasture & 4 & Leaf-tube formation & 26,0 & 5,2 & 4,2 & 5,2 \\
\hline Controlled & 6 & Tillering & 24,0 & 4,0 & 3,6 & 5,8 \\
\hline
\end{tabular}

Note $^{*}$ - non-systematic grazing is effective only when milk yield of cows is up to 18 liters daily, a pasture system - up to 20 liters, and a controlled one -24 liters.

High level of intensification of grassland farming in the developed European countries is, first and foremost, the result of a deep interrelation of science and agribusiness. Introduction of innovative technologies and recommendations on grassland farming in the Western European countries is carried out mainly by the extension services that have their networks throughout the country.

Analysis of old pastures in Ukraine as a whole shows that they have been grassed on the basis of grasses intended for hay (Timothy (Phleum pratense L.), cocksfoot (Dactylis glomerata L.), and Red clover (Trifolium pratense L.). Production of green fodder from such grasses without application of mineral fertilizers is not effective. As a result, in 2-3 years there remains mainly Cocksfoot (Dactylis glomerata $L$.) and then the grass stand is weeded with Quackgrass (Elytrigia repens (L.), which ensure the longevity of this pasture. Nutritional value of such grass stand is low, it is impossible to obtain milk yield of over 3,000 kg per head annually on the hay pasture without additional feeds. In most agroformations, pastures are usually low productive and remain unchanged for up to 15 years of their use.

The Institute of Feed Research and Agriculture of Podillia of NAAS has examined phytocenotic activity, competitiveness and productive effect of new varieties of perennial grasses created by the methods of adaptive selection. The course of programmable succession of artificial agrophytocenoses with different rhythm of biomass growth under conditions of pastoral influence has been investigated. It has been noted that in the regime of coenotic closeness of grass stands, in the first years of grass life there can be observed a change in the composition of cultural dominants in the grass mixtures, i.e. in the early grass stands the signs of violentness are possessed by coenotically active species, namely, Tall fescue (Festuca arundinacea Schreb) (52.7-86.9\%), Meadow fescue (Festuca pratensis Huds.) (52, 5-77.2\%), Cocksfoot (Dactylis glomerata L.) (19.5$58.7 \%$ ), Tall oatgrass (Arrhenatherum elatius (L.) (20.3-30.9\%); in mid mixtures in the case of the first two above-mentioned dominant species, these competitive properties have been possessed by Smooth brome grass (Bromopsis inermis (Leyss.) (21.2-38.2\%) and Meadow brome (Bromopsis riparia (Rehm.) (20.8-41.1\%); while in the late agro-phytocenoses Red fescue (Festuca rubra L.) $(12,9-21,1 \%)$ and Slender wheat grass (Roegneria trachycaulon (Link) 12,8-14,7\%) should be regarded as the following chain by the dominant species in the ranking of species by degree of violentness (Fig. 1) [4]. 


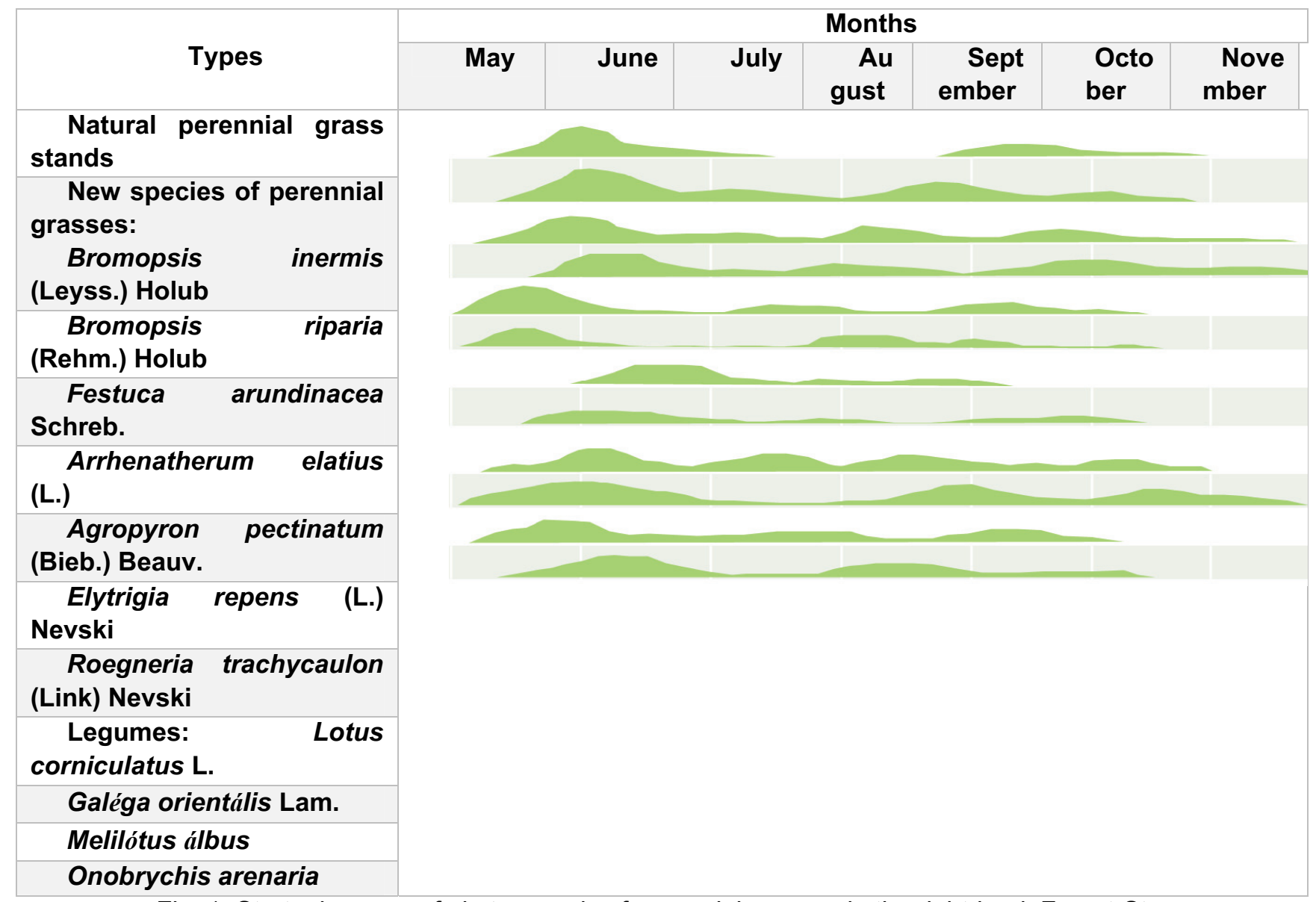

Fig. 1. Strategic range of phytocenosis of perennial grasses in the right-bank Forest-Steppe

Based on them, the models of pasture grass stands for the dairy cattle breeding for regions with unstable soil moisture supply have been improved, and the technology of creation of cultivated pastures that ensures guaranteed production of 27-30 t/ha of pasture forage or 5.0-5.5 t/ha of feed units during 5 years of use has been developed (Table 3-4). The results of testing the developed balanced pasture grass mixtures reveal their economic efficiency, longevity duration, and high feed value. Thus, $50 \%$ content of White clover (Trifolium repens $\mathrm{L}$.) in the grass mixture completely solves the protein problem, and $20 \%$ content of sugars in Perennial ryegrass (Lolium perenne L.) (instead of $8 \%$ in Cocksfoot (Dactylis glomerata L.) substitute expensive carbohydrate forage (corn, beets, molasses and partially concentrates).

Table 3-Qualitative indices of the developed agrophytocenoses of perennial grasses

\begin{tabular}{|c|c|c|c|c|c|c|c|}
\hline $\begin{array}{c}\text { Grass stand } \\
\text { model }\end{array}$ & $\begin{array}{c}\text { Height of } \\
\text { grass, cm }\end{array}$ & $\begin{array}{c}\text { Digestibility } \\
\text { of dry matter, } \\
\%\end{array}$ & $\begin{array}{c}\text { Digestible } \\
\text { protein } \\
\text { content, \% }\end{array}$ & $\begin{array}{c}\text { Crude fiber } \\
\text { content, \% }\end{array}$ & $\begin{array}{c}\text { Netergent } \\
\text { fiber } \\
\text { content, } \\
\%\end{array}$ & $\begin{array}{c}\text { Digestibility of } \\
\text { neutral-detergent } \\
\text { fiber, \% }\end{array}$ & $\begin{array}{c}\text { Sugar } \\
\text { content, \% }\end{array}$ \\
\hline Pasture & $10-15$ & $70-80$ & $16-18$ & $\leq 20$ & $\leq 40$ & $\geq 70$ & $\geq 8$ \\
\hline Hay-cut & $40-50$ & $65-75$ & $14-17$ & $\leq 27$ & $\leq 50$ & $\geq 70$ & $\geq 3,5$ \\
\hline
\end{tabular}

The influence of the territory terrain on the temporary and spatial dynamics of the productivity indicators of perennial grasses and the adaptive response of plants when grown on the slopes of the river arroyos is studied, manifestation of the patterns of sod formation is examined, and differentiation of the vegetation cover of artificial perennial grasses depending on the vertical profile of the slopes of the southwest and northeast exposition on the pasture forage lands with $9-12^{\circ}$ slope angle is determined. There have been selected the most stable and productive perennial grass mixtures for grassing slopes and developed the technology of creating perennial pastures on the slopes that guarantees output of 20-25 t/ha of pasture forage or 4.0-4.5 t/ha of dry matter, which is equivalent to 3.8-3.9 t/ha of feed units under 1.3-1.8 return on production costs for pasturing and its 135$190 \%$ profitability during 5 years of use [4]. 
Table 4 - Productivity and safety of perennial agrophytocenoses of pasture use

\begin{tabular}{|c|c|c|c|c|c|c|}
\hline \multirow{3}{*}{$\begin{array}{c}\text { Model of } \\
\text { agrophytocenosis }\end{array}$} & \multicolumn{6}{|c|}{ Key indicators of forage productivity and safety } \\
\hline & \multirow{2}{*}{$\begin{array}{c}\text { Productive } \\
\text { longevity, } \\
\text { years }\end{array}$} & \multirow{2}{*}{$\begin{array}{c}\text { Output of } \\
\text { feed units, } \\
\text { t/ha }\end{array}$} & \multirow{2}{*}{$\begin{array}{c}\text { Sugar and protein } \\
\text { ratio }\end{array}$} & \multirow{2}{*}{$\begin{array}{c}\text { Concentration of } \\
\text { net energy of } \\
\text { lactation in dry } \\
\text { matter, } \mathrm{MJ} / \mathrm{kg}\end{array}$} & \multicolumn{2}{|c|}{$\begin{array}{c}\text { Indicators of grass forage } \\
\text { safety } \\
\text { (According to SSTU } \\
4685: 2006)\end{array}$} \\
\hline & & & & & $\begin{array}{c}\text { Nitrate } \\
\text { content } \\
\mathrm{mg} / \mathrm{kg}\end{array}$ & $\begin{array}{l}\text { Nitrite } \\
\text { content } \\
\mathrm{mg} / \mathrm{kg}\end{array}$ \\
\hline \multirow{2}{*}{$\begin{array}{c}\text { Traditional } \\
\text { pasture }\end{array}$} & \multirow{2}{*}{$3-4$} & \multirow{2}{*}{4,53} & \multirow{2}{*}{$1: 0,7$} & \multirow{2}{*}{5,94} & \multicolumn{2}{|c|}{ Within the norm } \\
\hline & & & & & 487,02 & 8,87 \\
\hline \multirow{2}{*}{ Adapted pasture } & \multirow{2}{*}{$4-5$} & \multirow{2}{*}{4,82} & \multirow{2}{*}{$1: 0,6$} & \multirow{2}{*}{6,06} & \multicolumn{2}{|c|}{ Within the norm } \\
\hline & & & & & 488,12 & 8,72 \\
\hline \multirow{2}{*}{$\begin{array}{l}\text { Pasture of } \\
\text { extended } \\
\text { longevity }\end{array}$} & \multirow[b]{2}{*}{$5-6$} & \multirow[b]{2}{*}{5,16} & \multirow[b]{2}{*}{$1: 0,8$} & \multirow[b]{2}{*}{6,13} & \multicolumn{2}{|c|}{ Within the norm } \\
\hline & & & & & 489,07 & 8,65 \\
\hline
\end{tabular}

Optimal terms of additional sowing of grasses in the sod of old grasses under the surface improvement of drylands of the Forest-Steppe, which cause an increase of 0.5-1.5 t/ha of dry mass in the first year of use, have been determined. The expediency of application of biopreparations, growth stimulators and perspective methods of grassland fertilization, which increase their productivity from 2.0 to 4.4 t/ha of dry matter, is substantiated [12].

Based on the use of the developed scientific parametric base and special methodology, it is possible to obtain specific recommendations by the species and variety composition of the mixtures of perennial grasses that are most adapted to specific growing locations and methods of use. Scientific approaches to the territorial combination of such developments and implementation of the original and elite seed production, which allows the consumer to receive seeds of perennial grasses based on the ecological and biological characteristics of varieties, recommendations of experts, and prevents them from the use of three or four types of grasses that are the most common in the market.

Thus, productivity of grazing systems largely depends on the available soil and climatic conditions, species composition of legume-cereal grass mixtures, technologies of their cultivation and use, and the level of livestock pressure per unit of area. At the same time, adaptive potential of innovative technologies of the field and grassland forage production is very high, which is very important under conditions of the climate change. A significant share of forage grasslands and perennial grasses in the structure of agrolandscapes ensures their productivity, sustainable development of the forage base in all natural and climatic zones of the country, plays an ecological role in conserving and increasing soil fertility, and protecting it from erosion.

\section{Conclusions.}

Effective use of the natural forage lands under conditions of the climate change requires innovative approaches to the organization of grassland farming systems that can maintain productive longevity of perennial grasses, increase their yields, and enhance milk production in the united communities in terms of the European integration.

Modern development of grassland forage production should be based on the ecological and biological principles of formation of the dominant pasture agrophytocenoses adapted to specific natural and territorial conditions, differentiated application of energy subsidies in the environmental protection technologies for the improvement of grasslands and creation of highly productive biogeocenoses. Current extensive, unsystematic use of pastures should be replaced by fundamentally new grazing systems with the elements of intensification that will mitigate the risks from the impact of climate change, will ensure the optimal pressure of livestock per unit of area depending on the climatic and anthropogenic factors. Regular monitoring of the grassland farming systems will allow us to implement more effective management, control the quality and safety of forages, and affect the degree of technological and environmental pressure on forage grasslands.

Introduction of innovative developments in the grassland farming systems will stop further degradation of natural forage lands, increase livestock productivity in the public sector, and create preconditions for increasing livestock number and sustainability of traditional dairy farming to climate change. Positive effect is also associated with the improvement of business environment, enhancement of competitiveness of household 
products and goods, available access to local (and foreign) markets, and improvement of the social and economic conditions in the rural areas.

\section{References}

1. Kurhak V.H. (2010). Luchni ahrofitotsenozy. [Onion agrophytocenoses ]. Kyiv: DIA,. 376 p. [in Ukrainian].

2. Bohovin A.V., Sliusar I.T., Tsarenko M.K. (2005). Travianysti bioheotsenozy, yikhnie polipshennia ta ratsionalne vykorystannia. [Herbal biogeocoenoses, their improvement and rational use]. Kyiv: Ahrarna nauka, 360 p. [in Ukrainian].

3. Petrychenko V., Zadorozhny V., Veklenko Y. (2011). State and prospects of the use of natural grasslands in Ukraine. Grassland farming and land management systems in mountain regions. Book of abstracts 16th Symposium of the European Grassland Federation. Gumpenstein, Austria. August 29th. August 31th. P. 111.

4. Biodiversity and Animal Feed Future Chal-lenges for Grassland. Production Proceeding of the 22 th General Meeting of the European Grassland Federation Uppsala, Sweden, June, 9-12, 2008. V. 13. P. 1035.

5. Bohovin A.V., Ptashnik M.M., Dudnyk S.V. (2017). Vidnovlennia produktyvnykh ekolohichno stiikykh travianystykh bioheotsenoziv na antropotransformovanykh edafotopakh: monohr. [Restoration of productive ecologically stable grass biogeocoenoses on anthropo-transformed foodafotopes: monograph]. Kyiv: Tsentr uchbovoi literatury. 356 p. [in Ukrainian].

6. Permanent and Temporary Grassland Plant, Environment and Economy. Proceeding of the 14 th Symposium of the European. Grassland Federation Ghent, Belgium, 3 - 5 September, 2007. V. 12. P. 595.

7. Kulakovskaya T.V., Willem Prins, Willy Kessler et al. (2010). Mnogofunkcionalnost razvitiya i ispolzovaniya lugopastbishnogo hozyajstva $v$ Evrope. [Multifunctional development and use of grassland farming in Europe]. AGROPANORAMA. 3`(79). C. 14-18. [in Russian].

8. Buhryn L.M., Kotiash U.O., Panakhyd H.la. (2015). Produktyvnist dovhotryvalykh luchnykh travostoiv zalezhno vid udobrennia. Peredhirne ta hirske zemlerobstvo i tvarynnytstvo. [Productivity of long-range meadow grasses depending on fertilization]. Peredgirne ta girske zemlerobstvo i tvarinnictvo. V. 58 (1). P. 13-16. [in Ukrainian].

9. Petrichenko V.F., Veklenko Yu.A. (Kosolapov V.M. Ed.). (2010). Nauchnye osnovy razvitiya adaptivnogo lugovogo kormoproizvodstva $v$ Ukraine. Adaptivnoe kormoproizvodstvo. [Scientific bases of adaptive meadow feed production development in Ukraine. Adaptive feed production]. Moskva: Ugreshskaya tipografiya. $274 \mathrm{p}$. [in Russian].

10. Veklenko Yu.A., Kovtun K.P., Bezvuhliak L.I. et al. (2013). Ahroekolohichne obgruntuvannia adaptyvnykh resursooshchadnykh tekhnolohii stvorennia ta vykorystannia bahatorichnykh kormovykh ahrofitotsenoziv. [Agroecological substantiation of adaptive resource-saving technologies for the creation and use of perennial forage agrophytocenoses]. Visnyk ahrarnoi nauky. P. 78-83. [in Ukrainian].

11. Veklenko Y., Kovtun K., Korniychuk O. et al. (2012). The impact of leaf dressing with Kristalon on the pro-ductivity of grass-legume mixtures in a 3-cut harvesting regime. Grassland Science in Europe. V. 17. Proceedings of the 24th General Meeting of the European Grassland Federation. Lublin, Poland. $3-7$ June P. 196 - 201. 